\title{
Vloga uporabniških preferenc v urbani akupunkturi: preoblikovanje praznih javnih odprtih prostorov v Teheranu
}

Avtorji v članku obravnavajo pogosto krhko povezavo med javnimi prostori in širšim okoljem. $S$ pristopom urbane akupunkture na neizkoriščenih odprtih javnih prostorih se lahko mestno tkivo revitalizira $\mathrm{z}$ manjšimi prostorskimi posegi, zasnovanimi v skladu s preferencami lokalne skupnosti. Avtorji na podlagi preferenc prebivalcev in mnenj strokovnjakov proučujejo posege na neizkoriščenih mestnih zemljiščih. Na primeru praznega odprtega javnega prostora $\mathrm{v}$ Teheranu proučujejo preference javnosti z družbenega, oblikovalskega in estetskega vidika, pri čemer uporabljajo opisno in analitično metodo. V prvi fazi opravljene raziskave so bila proučena mnenja šestih strokovnjakov, katerih vsebina je bila razvrščena v kategorije, v drugi fazi pa bile so teme in podteme, izluščene iz prve faze, vključene v anketo o javnih preferencah. Skupno število pravilno izpolnjenih (veljavnih) vprašalnikov je bilo 165. Po analizi odgovorov, pridobljenih z anketo, je bilo opravljenih 22 osebnih intervjujev. Izsledki raziskave kažejo, kateri posegi so v lokalni skupnosti bolj zaželeni.

Ključne besede: prazni javni odprti prostori, urbana akupunktura, posegi v mestni prostor, uporabniške preference, Iran 


\section{Uvod}

Neizkoriščeni odprti prostori so del infrastrukture, ki lahko izboljša družbene in ekološke razmere (Kremer idr., 2013), in so alternativa sodobnim urejenim javnim prostorom (Kamvasinou, 2011). Večje zavedanje o vrednosti praznih mestnih zemljišč za javnost je ključno za bolǰ̌e razumevanje njihovih ekoloških in družbenih koristi (Kim, 2016). Da bi krajine, ki niso varne in privlačne, lahko spremenili v okolja, ki izboljšajo družbeno-ekološke sisteme (Folke, 2006; Wals in Wals, 2015), bi bilo treba podrobneje proučiti zadevne posege v družbene in okoljske razmere, upravljavske prakse, rabo prostora in na prazna zemljiǐ̌ca (Kremer idr., 2013).

Glavna prednost vključenosti lokalne skupnosti v prenovo neizkoriščnih odprtih prostorov je ta, da je njihova končna oblika skladna z zamislimi in željami stanovalcev (Kim idr., 2020). Za doseganje večje javne podpore projektom prenove neizkoriščnih odprtih prostorov je zelo pomembno oblikovanje učinkovitih strategij, ob tem pa je javno mnenje o praznih zemljiščih še vedno slabo raziskano (Kim in Miller, 2017). Uporaba pristopa urbane akupunkture na praznih zemljiščih lahko zmanjša družbene težave. Sodobna mesta je pogosto treba oblikovati z makrostrukturnimi posegi (Kermani, 2016), kar lahko v mestih, ki se spopadajo z družbenimi težavami, povzroči velik delež praznih zemljišč (Zhang idr., 2019). Urbanizem se osredotoča na mikroizkušnje mestnih prostorov, urbana akupunktura pa zagotavlja makropogled nanje in zajema izvajanje manjših projektov, ki spodbujajo ekološki in družbeni razvoj v grajenem okolju (Casagrande, 2015). V prihodnje se bodo mesta spopadala s pomanjkanjem prostora in virov, zato so lahko prazna zemljišča priložnost (Németh in Langhorst, 2014; Dubeaux in Cunningham Sabot, 2018) za oblikovanje uporabnih prostorov (Newman idr., 2018), ki lahko uravnovesijo in stabilizirajo soseske. V 20. stoletju so se prazni, neizkorišceni odprti javni prostori večinoma obravnavali kot luknje v prostorski zgradbi mest (Newman in Kim, 2017). Danes veljajo za sestavni del navedene zgradbe, vpliv manjših prostorskih posegov $\mathrm{v}$ okviru urbane akupunkture pa se proučuje z vidika funkcije (Kim, 2016). Izsledki raziskav opuščnih prostorov, ki se osredotočajo na ključne vloge in preference njihovih uporabnikov (Lynch, 1977; Trancik, 1986; Thompson, 2002), kažejo, da je smiselno navedene preference upoštevati pri izbiri vrste prostorskih posegov. Vrzel med teorijo in prakso je opazna že nekaj časa. Raziskava, predstavljena v tem članku, se osredotoča na primer iz Teherana, pri katerem so bili neizkoriščeni javni prostori prepoznani kot priložnost za urbano prenovo, ki lahko izboljša ujemanje značilnosti mestnih prostorskih posegov in želja prebivalcev.
V nadaljevanju je navedeno teoretično ozadje, na podlagi katerega je mogoče proučevati dejavnike, ki pomembno vplivajo na preference in želje ljudi v zvezi s posegi na praznih odprtih javnih prostorih. V članku avtorji torej proučujejo preference in želje uporabnikov, ob upoštevanju katerih se lahko doseže večje ujemanje med značilnostmi mestnih prostorskih posegov in preferencami lokalne skupnosti. Najprej je naveden pregled literature, sledita pa razlaga uporabljenega gradiva in metod ter predstavitev izsledkov. V sklepu so povzete ključne ugotovitve $\mathrm{v}$ povezavi z osrednjim raziskovalnim vprašanjem in so podana priporočila za prihodnje raziskave.

\section{Pregled literature}

Na podlagi razumevanja praznih zemljišč kot potencialno dragocenih naravnih dobrin lokalne skupnosti se lahko izboljša okoljska kakovost sosesk (Kim, 2016). Neizkoriščni javni odprti prostori so v literaturi opredeljeni zelo različno, in sicer kot praznine v zgradbi mest (Trancik, 1986), nikogaršnja zemlja (Mariani in Barron, 2014), prazna zemljišča in nezasedeni kraji, razpoložljivi za spontano uporabo (Lokman, 2017), in urbane praznine (Newman in Kim, 2017), ki se dojemajo kot javni prostori (Kamvasinou, 2011; Kim, 2016).

Kot navaja de Sola-Morales (2014), prazna območja obsegajo nenavadne, običajno prostorsko neurejene kraje, ki lahko vseeno razvijejo nove, pozitivne prostorske lastnosti (Mariani in Barron, 2014). Povsem neurejeno okolje pa pogosto spodbuja neprimerno družbeno vedenje (Unt idr., 2014). Čedalje več objavljenih raziskav nakazuje, da lahko prenova neizkoriščenih javnih prostorov privede do logičnih in značilnih aktivnosti (Drake in Lawson, 2014; Pearsall in Lucas, 2014), povezanih z najrazličnejšo prostorsko rabo, kot so območja za rekreacijo (Johnson idr., 2014). Ker navedeni prostori ne opravljajo več svoje nekdanje funkcije, so postali prazni in dostopni vsem ter so na voljo, da se jim določi nova raba (Franck in Stevens, 2007). De Sola-Morales (2014) prazne javne prostore razume v smislu evokativnega potenciala mesta, Armstrongova (2006) pa jih dojema kot latentne kraje s posebnimi lastnostmi, ki bi jih bilo treba razumeti in upoštevati pri ustvarjanju predvidljivih ureditev.

V 21. stoletju prevladuje prepričanje, da so minimalni prostorski posegi najpomembnejša strategija urbanističnega oblikovanja (Enia in Martella, 2019). Urbana akupunktura zajema manjše posege (Colorni idr., 2017) in je nov način spodbujanja urbane prenove (Casanova in Hernandez, 2015). Je eden izmed pristopov $\mathrm{k}$ projektom urbane prenove ali gradnje ter omogoča upoštevanje družbenih, ekoloških in okoljskih vprašanj (Daugelaite idr., 2018) in ustvarjanje skupnih prostorov za lokalne prebivalce. Vključenost lokalne skupnosti v 
Preglednica 1: Značilnosti posegov

\begin{tabular}{lll}
\hline Št. & Značilnost & Viri \\
\hline 1 & Manjši obseg (mikroposeg) & $\begin{array}{l}\text { Marzi in Ancona, 2004; Acebillo, 2006; Cheng in Niu, 2010; Radstaak, 2012; Casagrande, 2015; Ao- } \\
\text { uad, 2016; Campelo in Fontenele, 2017; Colorni idr., 2017; Grifoni idr., 2017; Bugaric, 2018; Cerro, } \\
\text { 2018; Daugelaite idr., 2018; Rau in Hutchison, 2019. }\end{array}$ \\
\hline 2 & Natančnost & Shieh, 2006; Campelo in Fontenele, 2017. \\
\hline 3 & $\begin{array}{l}\text { Spodbujajo prenovo celotne } \\
\text { okolice }\end{array}$ & $\begin{array}{l}\text { Shieh, 2006; Cheng in Niu, 2010; de Sola-Morales 2014; Campelo in Fontenele, 2017; Colorni idr., } \\
\text { 2017; Grifoni idr., 2017. }\end{array}$ \\
\hline 4 & Hitra izvedba & Marzi in Ancona, 2004; Colorni idr., 2017; Enia in Martella, 2019. \\
\hline 5 & Nizki stroški & Cheng in Niu, 2010; Rau in Hutchison, 2019. \\
\hline 6 & Pristop od spodaj navzgor & Unt in Bell, 2014; Gadanho, 2015; Aouad, 2016; Campelo in Fontenele, 2017; Bugaric, 2018, \\
\hline 7 & Lokalne narave & Tortosa idr., 2010; De Wit, 2014; Unt in Bell, 2014; Casagrande, 2015; Houghton idr., 2015; Aouad, \\
\hline 8 & Taktičnost & 2016; Grifoni idr., 2017; Lastra in Pojani, 2018. \\
\hline
\end{tabular}

urbanistično načrtovanje in oblikovanje je ključna, dosedanje raziskave pa poudarjajo, da so za zadovoljevanje lokalnih potreb in želja potrebne raznolike oblikovalske smernice (Polat in Tümer Yildiz, 2019). V projekte urbane akupunkture so vključeni tudi prebivalci, zato ti projekti omogočajo zadovoljevanje družbenih potreb. Urbana akupunktura sledi strategiji ciljno naravnanih minimalnih posegov (Daugelaite idr., 2018), pri spreminjanju in izboljšanju kakovosti življenja prebivalcev pa upošteva njihove potrebe in mnenja (Bugaric, 2018). Po svetu lahko najdemo najrazličnejše primere urbane akupunkture, od uvedbe nove tradicije do spreminjanja navad (Lerner, 2014), ki jih lahko krajinski arhitekti in urbanisti uporabljajo kot model za izboljšanje kakovosti življenja mestnih prebivalcev. Cilj urbanističnega oblikovanja je ustvariti dobro organizirano strukturo in občutek mesta po meri človeka (Behzadfar idr., 2014). Številni avtorji navajajo, da lahko manjši pametni prostorski posegi na posameznem območju pozitivno vplivajo na okolico (Lydon idr., 2015). Po mnenju Kennetha Framptona imajo novi projekti kot posegi v grajeno okolje moralno nalogo, da spodbudijo obnovo svoje okolice (Shieh, 2006). Omenjeni projekti so bili prepoznani kot pomembni v mestnih okoljih, saj se z njimi poudarjajo naravna dinamika in nizki stroški izvedbe (Daugelaite idr., 2018), so koristni v državah $\mathrm{v}$ razvoju, kjer imajo vlade in ustanove omejene vire, in krepijo neposredno vključenost ljudi, ki v teh okoljih živijo.

Urbane akupunkture ustvarjajo obsežnejše spremembe, kot je bilo sprva predvideno (Lydon idr., 2015; Lastra in Pojani, 2018), z arhitekturnim pristopom ravno prave mere pa se lahko pri tovrstnih posegih izvedejo ustrezne in potrebne prilagoditve kraju (Enia in Martella, 2019). V preglednici 1 so na podlagi pregleda literature navedene osnovne značilnosti, ki bi jih morali imeti manjši posegi v mestne prostore, kot so območja med uličnimi bloki, površine pred stavbami, manjši parki in manjša prazna zemljišča.
Glavna prednost vključenosti lokalne skupnosti v prenovo neizkoriščenih, praznih prostorov je ta, da njihova končna oblika izraža želje stanovalcev, zato je navedeno vključenost smiselno okrepiti (Kim idr., 2020). Čeprav je pomembno oblikovati učinkovite strategije za doseganje večje javne podpore projektom prenove, je bilo doslej opravljenih le malo raziskav javnega mnenja o praznih zemljiščih (Kim in Miller, 2017). Raziskave so se v glavnem osredotočale na okoljske značilnosti, ki vplivajo na to, kako ljudje dojemajo krajino in območja (Lafortezza idr., 2008; Hofmann idr., 2012; Svobodova idr., 2012; Ruelle idr., 2013). Nekateri raziskovalci so proučevali vizualne preference $\mathrm{v}$ povezavi z ekološko sanacijo krajin (Hands in Brown, 2002; Tveit idr., 2006) ter načrtovanjem in oblikovanjem krajin (Ahern, 1999; Greenberg in Lewis, 2000; Ruelle idr., 2013), podobnih raziskav, ki bi obravnavale prazne javne odprte prostore, pa je še vedno zelo malo. Vizualne preference so pomemben dejavnik proučevanja pripravljenosti in želje stanovalcev, da sodelujejo v procesu posodobitve mestnega prostora (Zhao idr., 2020). Čeprav ima uporaba fotografij nekatere omejitve (Daniel, 2001; Palmer in Hoffman, 2001; Steinitz, 2001), je to pomembna metoda za vrednotenje vizualnih preferenc javnosti.

\section{Gradivo in metode \\ 3.1 Območje raziskave}

Čeprav javni prostori v Teheranu na splošno uporabniku niso najbolj prijazni, so dovolj prehodni, da omogočajo razvoj spontanih dogodkov in aktivnosti (Khorshidifard, 2014). Pristojne organizacije si prizadevajo izboljšati ekološko kakovost zelenih površin in jih primerno urediti, vendar ne morejo obnoviti mestne mreže zelenih površin, ki je zaradi nenadzorovane rasti mesta postala preveč razdrobljena (Bahrami idr., 2012). Dragocene naravne prvine $\mathrm{v}$ mestu se rušijo, zato nastajajo številne težave. Ker je Teheran velemesto, v katerem je prostih zemljišč 


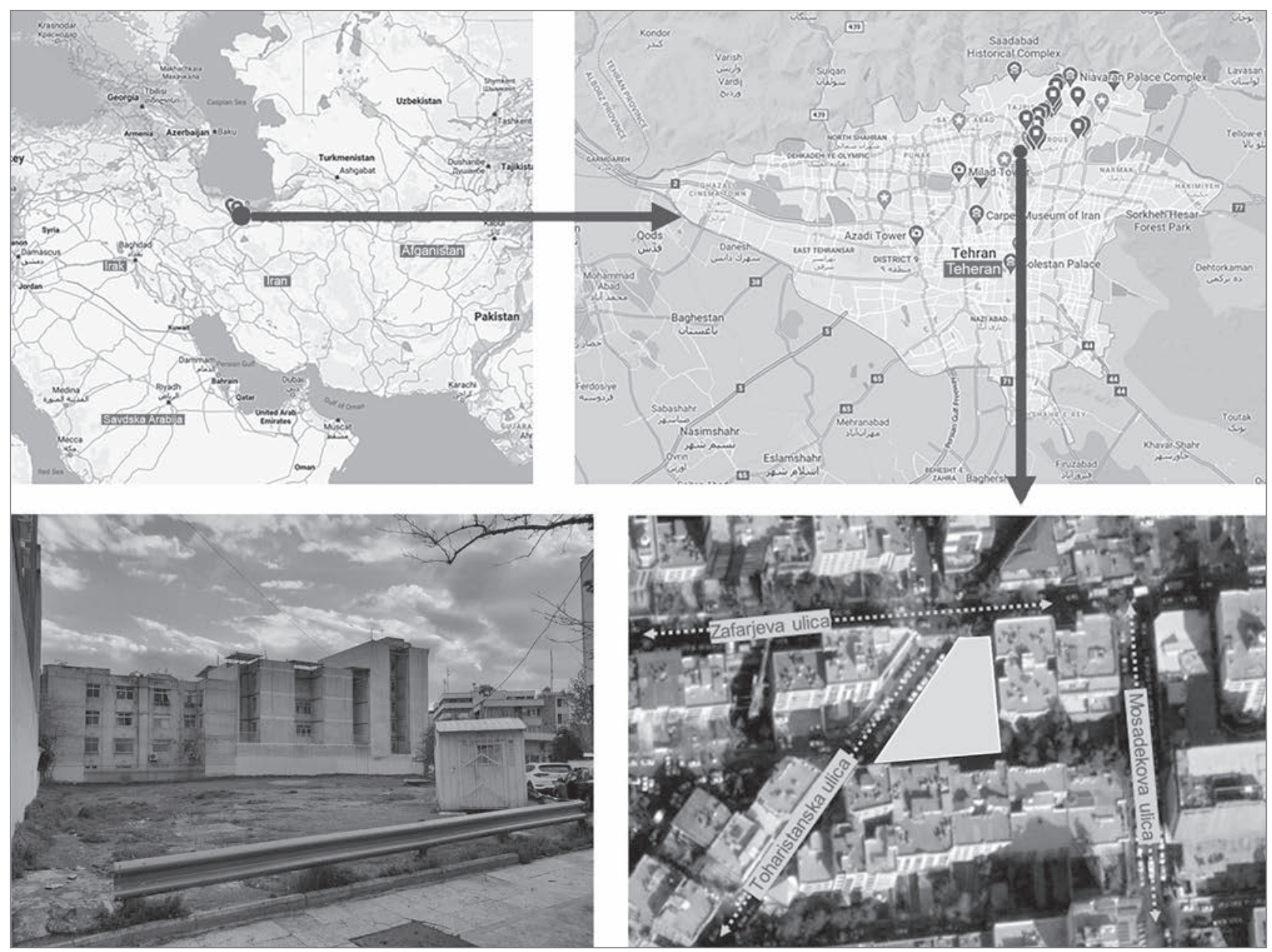

Slika 1: Lokacija območja raziskave (ilustracija: avtorji; vir: Mapdata, 2020)

zelo malo, je lahko uporaba urbane akupunkture na neizkoriščenih javnih prostorih zelo koristna. Avtorji so mesto izbrali za raziskavo prav zaradi raznovrstnosti tamkajšnjih praznih odprtih prostorov, pri čemer je bil njihov glavni cilj proučiti možnost urbanih akupunktur na mikroprostorih, ki ostajajo neizkoriščeni. Na podlagi intervjujev s stanovalci so med manjšimi odprtimi neizkoriščenimi prostori v stanovanjskih soseskah izbrali ustrezno območje za študijo primera. To je v eni izmed sosesk v severnem predelu Teherana, imenovanem Zafar, v katerem živi 70.677 ljudi. Kot je razvidno s slike 1, sosesko na severu omejuje Zafarjeva ulica, na zahodu pa Toharistanska ulica.

\subsection{Raziskovalna metoda}

Raziskava je potekala v več fazah, pri čemer so avtorji najprej izbrali fotografije prostorskih posegov iz različnih mestnih okolij, ki bi lahko bile podlaga za preoblikovanje izbranega območja raziskave. Nato so fotografije razvrstili v tri kategorije glede na vrsto izvedenega posega: družbeno, oblikovalsko ali estetsko. V naslednjem koraku so vsakega izmed sodelujočih strokovnjakov prosili, naj izbere po tri fotografije, ki so najbolje ponazarjale značilnosti vsake kategorije. Da bi določili preference lokalne skupnosti, so na koncu med stanovalci soseske opravili anketo po metodi analitičnega hierarhičnega procesa (v nadaljevanju: AHP), v kateri so uporabili vprašalnik s fotografijami.

AHP je metoda odločanja, ki se uporablja, ko je treba upoštevati vpliv več dejavnikov, kar lahko oteži proces odločanja. Ta proces odločevalcem omogoča, da na podlagi zbranih informacij bolje razumejo vprašanja, značilna za konkretne situacije, na tej podlagi pa lahko oblikujejo hierarhično strukturo odvisnih dejavnikov (Nekhay in Arriaza, 2016; Saaty in De Paola, 2017). Ključno je oblikovati hierarhijo med različnimi posegi na majhnih neizkoriščenih odprtih prostorih in določiti ključne dejavnike, ki vplivajo na preference stanovalcev glede javnih prostorov. $S$ to metodo se lahko lažje merijo vplivi prostorskih izboljšav na sosesko in celotno mesto (Mondini idr., 2018). Po spletni anketi med stanovalci soseske so bili z 22 anketiranci po spletu opravljeni še osebni intervjuji. 


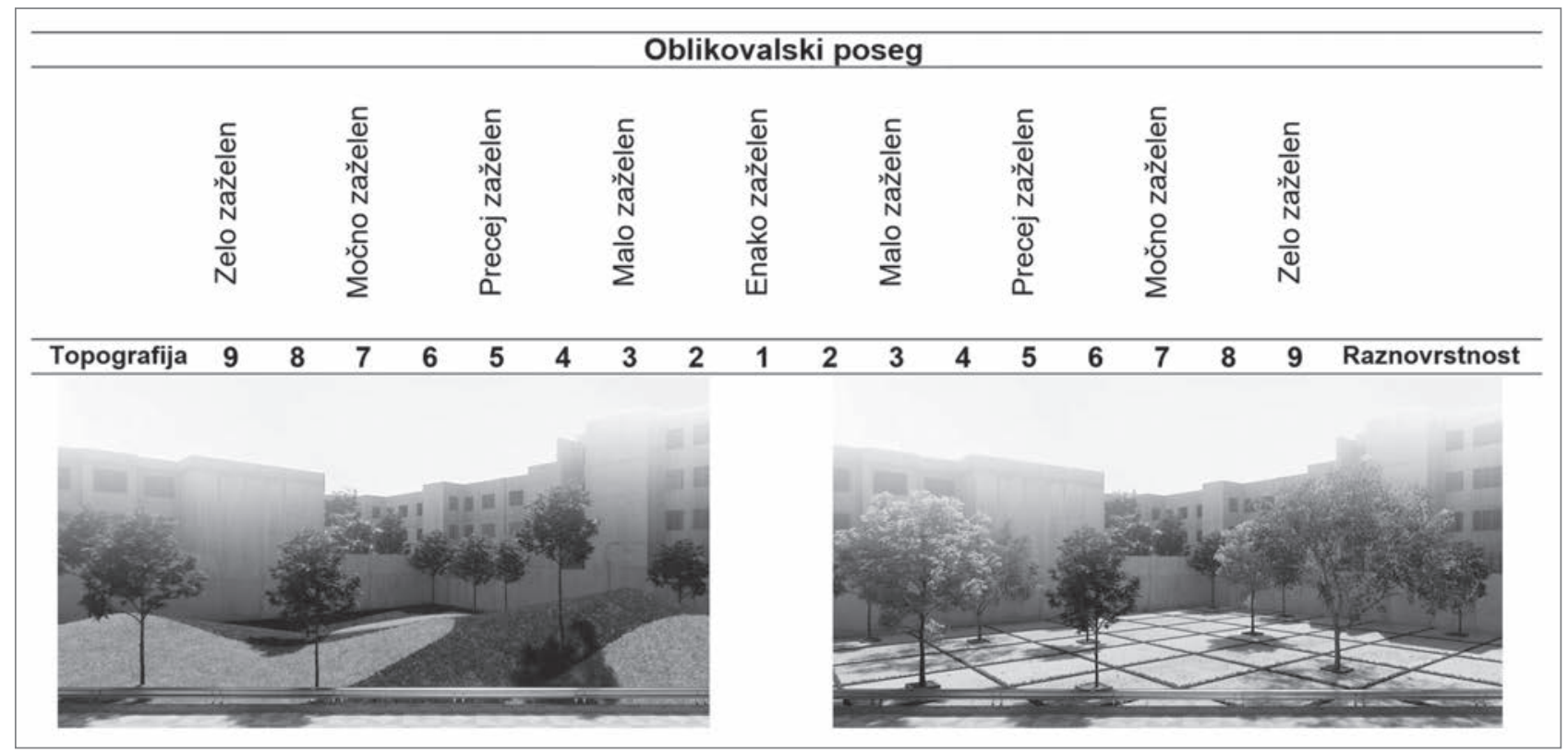

Slika 2: Primer parne primerjave po metodi AHP (prirejeno po Peng, 2019)

Preglednica 2: Hierarhija odločanja

\begin{tabular}{|c|c|c|}
\hline 1. raven: & 2. raven: & 3. raven: \\
\hline cilj & kategorija & podkategorija \\
\hline \multirow{17}{*}{$\begin{array}{l}\text { Prostorski } \\
\text { poseg }\end{array}$} & \multirow{7}{*}{ Družbeni } & Sproščanje \\
\hline & & Igrišče \\
\hline & & Posedanje v kavarni \\
\hline & & Galerija na prostem \\
\hline & & Namizne igre \\
\hline & & Sedenje in počitek \\
\hline & & Šport in rekreacija \\
\hline & \multirow{5}{*}{ Oblikovalski } & Topografija \\
\hline & & Pravilna zasnova \\
\hline & & Raznovrstnost \\
\hline & & Gostota \\
\hline & & Nepravilna zasnova \\
\hline & \multirow{5}{*}{ Estetski } & Barva \\
\hline & & Vzorec \\
\hline & & Kip \\
\hline & & Instalacija \\
\hline & & Poslikava, stenski okras \\
\hline
\end{tabular}

\subsection{Oblikovanje ankete}

Raziskovalci so najprej zbrali 114 fotografij prostorskih posegov na različnih mestnih območjih, ki bi lahko bile podlaga za preoblikovanje izbranega praznega odprtega prostora. $\mathrm{Da}$ bi zožili izbor, so šest strokovnjakov z najmanj devetletnimi delovnimi izkušnjami z zadevnega področja (tri arhitekte, enega urbanista in dva krajinska arhitekta) prosili, naj izberejo fotografije, ki najbolje ponazarjajo značilnosti urbanih akupunktur (Shahhosseini idr., 2015), opredeljene v preglednici 1.V prvem
Preglednica 3: Demografske značilnosti intervjuvancev

\begin{tabular}{|c|c|c|c|c|}
\hline & & \multicolumn{3}{|l|}{ Spol } \\
\hline & & Ženski & Moški & Skupaj \\
\hline \multirow{3}{*}{ Starost } & 20-40 let & 9 & 8 & 17 \\
\hline & $41-60$ let & 2 & 1 & 3 \\
\hline & $>60$ let & 1 & 1 & 2 \\
\hline Skupaj & & 12 & 10 & 22 \\
\hline
\end{tabular}

krogu je bilo tako opredeljenih 72 fotografij, ki so jih strokovnjaki najpogosteje izbrali. Da je fotografija prišla v ožji izbor, so jo morali izbrati najmanj štiri strokovnjaki.

Kot je razvidno iz preglednice 2, je bilo 72 izbranih fotografij razvrščenih $\mathrm{v}$ tri kategorije glede na vrsto prikazanega prostorskega posega (družbeni, oblikovalski ali estetski). Za simulacijo sprememb v soseski (Norouzian-Maleki idr., 2018) na podlagi prostorskih posegov, izbranih na fotografijah, so avtorji uporabili programsko orodje SketchUp. Z metodo AHP so bili izbrani primerni posegi za proučevani neizkoriščni javni prostor. Prvi del ankete se je nanašal na demografske podatke anketirancev (preglednica 3) in njihovo trenutno prebivališce (morali so prihajati s proučevanega območja). Drugi del ankete se je osredotočal na ugotavljanje vizualnih preferenc anketirancev na podlagi metode AHP, pri čemer so morali anketiranci na 17-stopenjski lestvici oceniti 37 parov fotografij.

\subsection{Zbiranje podatkov}

Da bi proučili povezavo med značilnostmi prostorskih posegov in preferencami lokalne skupnosti, so avtorji izvedli spletno anketo $s$ fotografijami, ki je temeljila na metodi AHP. Pred 
Preglednica 4: Demografske značilnosti anketirancev

\begin{tabular}{lllllllll}
\hline & & \multicolumn{3}{c}{ Spol } & \multicolumn{5}{c}{ Zaposlitveni status } \\
\hline & & Ženski & Moški & Zaposlen & Gospodinja & Študent & Upokojenec & Brezposeln \\
\hline Starost & $20-40$ let & 78 & 51 & 12 & 10 & 29 & 1 & 77 \\
\hline & $41-60$ let & 10 & 11 & 2 & 1 & 1 & 5 & 12 \\
\hline Skupaj & $>60$ let & 6 & 9 & 1 & 2 & 0 & 7 & 5 \\
\hline
\end{tabular}

potrditvijo dokončne oblike ankete so jo tudi pilotno testirali. Anketiranci so bili izbrani z metodo snežne kepe, povabilo $\mathrm{k}$ sodelovanju v spletni anketi pa je bilo aprila in maja 2020 poslano 200 naključno izbranim stanovalcem soseske. Podatki, zbrani v anketi, so bili analizirani s programoma Excel in SPSS ter drugimi specializiranimi programskimi orodji. Rezultati so bili ovrednoteni in predstavljeni z uporabo opisne in sklepne statistike. Na koncu so bili z anketo, ki je temeljila na odprtih vprašanjih, pridobljeni še kvalitativni podatki.

Da bi avtorji še natančneje opredelili preference stanovalcev $\mathrm{v}$ zvezi s tremi kategorijami prostorskih posegov, so z 22 anketiranci opravili tudi spletne intervjuje. Intervjuvanci so bili izbrani z metodo slučajnih poti, podobni stratificiranemu vzorčenju, njihova porazdelitev po starosti in spolu pa je bila reprezentativna. Skupno je bilo intervjuvanih 12 žensk in 10 moških, njihova razporeditev po starostnih skupinah pa je razvidna iz preglednice 3 . Intervjuji so trajali približno 15-20 minut. Njihovi rezultati so predstavljeni v nadaljevanju.

\section{Rezultati in razprava}

Izmed 189 vrnjenih anket, jih je bilo veljavnih 165. Izpolnilo jih je 94 žensk in 71 moških, katerih demografske značilnosti so prikazane $\mathrm{v}$ preglednici 4 .

\subsection{Rezultati prvega dela ankete}

V prvem delu ankete so avtorji proučevali povezavo med izobrazbo, pogostostjo uporabe javnih prostorov in sodelovanjem $\mathrm{v}$ prostorskih posegih. Na podlagi stopnje značilnosti $p<0,05$ je bilo ugotovljeno, da bolj izobraženi anketiranci pogosteje sodelujejo pri prostorskih posegih. $\mathrm{V}$ preglednici 5 so predstavljene korelacije med stopnjo izobrazbe in sodelovanjem v prostorskih posegih na mestnih območjih.

Ker se pri urbani akupunkturi uporablja pristop od spodaj navzgor, je avtorje zanimalo tudi, kako pripravljeni so anketiranci sodelovati pri prenovi svojih sosesk. Kot je razvidno iz preglednice 6, mnogi anketiranci enkrat do dvakrat tedensko preživljajo prosti čas na javnih prostorih, hkrati pa so bolj pripravljeni sodelovati pri oblikovanju teh prostorov. $86,6 \%$
Preglednica 5: Povezava med izobrazbo in sodelovanjem v prostorskih posegih $v$ mestu

\begin{tabular}{llll}
\hline & & Izobrazba & Sodelovanje \\
\hline Izobrazba & Korelacija & 1 & $-0,164^{*}$ \\
\hline & $\begin{array}{l}\text { Značilnost } \\
\text { (dvostranski test) }\end{array}$ & 0,035 \\
\hline$n$ & 165 & 165 \\
\hline
\end{tabular}

Opomba: * Korelacija je statistično značilna pri stopnji 0,05 (dvostranski test).

anketirancev bi rado sodelovalo pri urejanju okolja, v katerem živijo, in samo 6,6 \% je takih, ki s tem nočejo imeti opravka.

Kot je razvidno s slike 3, najpogosteǰ̌e aktivnosti na javnih prostorih vključujejo sprehajanje (63,63\%), povezovanje z naravo $(52,12 \%)$, posedanje v kavarni ali restavraciji (48,48\%) ter sedenje in počitek $(44,84 \%)$. Da sta sprehajanje in povezovanje z naravo najpogostejši aktivnosti, se zdi smiselno, saj je večina anketirancev brezposelnih. Zaradi gneče na javnih prostorih jih stanovalci manj pogosto uporabljajo za udeleževanje dogodkov $(6,66 \%)$ in preživljanje prostega časa z otroki $(9,69 \%)$.

\subsection{Rezultati drugega dela ankete}

$\mathrm{Z}$ metodo AHP in parno primerjavo fotografij so bile utežene posamezne vrste prostorskih posegov (preglednice 7, 8 in 9). Na podlagi izbranih kriterijev in ocen $w$ na 9 -stopenjski lestvici so avtorji opredelili naslednjo matriko parnih primerjav:

$$
\left(\begin{array}{cccc}
w_{1} / w_{1} & w_{1} / w_{2} & \ldots & w_{1} / w_{n} \\
w_{2} / w_{1} & w_{2} / w_{2} & \ldots & w_{2} / w_{n} \\
\ldots & \ldots & \ldots & \ldots \\
w_{n} / w_{1} & w_{n} / w_{2} & \ldots & w_{n} / w_{n}
\end{array}\right) \times\left(\begin{array}{c}
w_{1} \\
w_{2} \\
\ldots \\
w_{n}
\end{array}\right)=\left(\begin{array}{c}
w_{1} \\
w_{2} \\
\ldots \\
n w_{n}
\end{array}\right)
$$

Na podlagi izračunanih lastnih vrednosti so bile ocenjene relativne uteži podkategorij, na podlagi česar sta bila določena največja lastna vrednost $\left(\lambda_{\max }\right)$ matrike primerjav in pripadajoči lastni vektor. Saaty (1990) je razvil tudi postopek določanja usklajenosti matrike primerjav, naveden v nadaljevanju.

Indeks usklajenosti (ang. consistency index ali CI) se izračuna z naslednjo enačbo: 
Preglednica 6: Povezava med pripravljenostjo stanovalcev, da sodelujejo pri oblikovalskih posegih v prostor, in pogostostjo uporabe javnih prostorov

\begin{tabular}{llllll}
\hline Pripravljenost sodelovati & \multicolumn{2}{l}{ Uporaba (v številu dni na teden) } & & Skupaj \\
\hline & $>4$ & $3-4$ & $1-2$ & 0 & 11 \\
\hline Težko rečem & 1 & 3 & 5 & 2 & 11 \\
\hline Nočem & 1 & 3 & 4 & 3 & 73 \\
\hline Mogoče & 8 & 7 & 45 & 8 & 70 \\
\hline Hočem & 12 & 7 & 97 & 26 & 165 \\
\hline Skupaj & 22 & 20 & & & \\
\hline
\end{tabular}

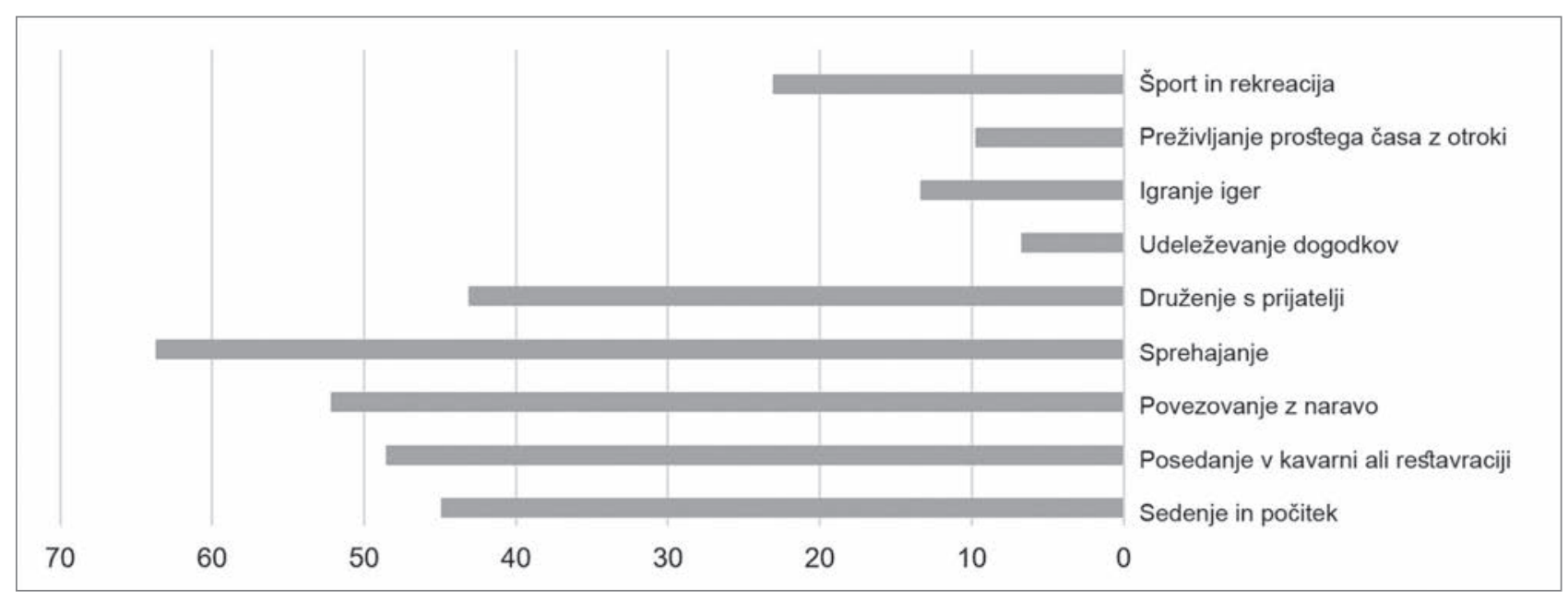

Slika 3: Izbrane aktivnosti na podlagi vprašanj izbirnega tipa

$$
\mathrm{CI}=\frac{\lambda_{\max }-\mathrm{n}}{\mathrm{n}-1}
$$

Usklajenostno razmerje (ang. consistency ratio ali CR) se izračuna z naslednjo enačbo:

$$
\mathrm{CR}=\frac{\mathrm{CI}}{\mathrm{RI}} \text {, }
$$

kjer je $\lambda_{\text {max }}$ največja lastna vrednost matrike, $n$ je rang matrike, RI (ang. random index) pa je slučajni indeks matrike, ki je povezan z njenim rangom.

Po Saatyju (2017) je primerjava slučajno generirana, če je vrednost CR enaka 1, usklajenost pa je večja, če je vrednost CR enaka 0 . Torej, če je $\mathrm{CR}<0,1$, so primerjave dovolj usklajene, če pa je CR $>0,1$, je treba matriko popraviti.

Na podlagi odgovorov, ki so jih stanovalci navedli v anketi, so bile izračunane uteži dejavnikov, ki so navedene v preglednicah 7,8 in $9 . S$ hierarhično analizo rezultatov vprašalnika so bili na podlagi dobljenih uteži opredeljeni najpomembnejši dejavniki, ki vplivajo na preference uporabnikov glede neizkoriščenih javnih odprtih prostorov.

\subsection{Rezultati vprašalnikov in osebnih intervjujev}

Kot je razvidno iz preglednic 7, 8 in 9, je bil najpomembnejši družbeni dejavnik sproščanje, najpomembnejši oblikovalski dejavnik je bila topografija in najpomembnejši estetski dejavnik je bila barva. V družbeni kategoriji (slika 4) sta bila dva dejavnika ovrednotena kot skoraj enako pomembna: namizne igre in galerija na prostem. Najpomembnejše je bilo sproščanje, nato pa posedanje $\mathrm{v}$ kavarni, igrišče ter šport in rekreacija.

Intervjuji z anketiranci so razkrili, da je stanovalcem soseske najmanj pomembno igrišče, bolj pomembni pa so jim prostori, na katerih se lahko sproščajo in počivajo. Primerjava fotografij prostorskega posega, ki bi omogočal sedenje in počitek, je pokazala, da je bila anketirancem pomembna tudi vrsta uličnega pohištva. Pozorni so bili na njegovo obliko in prilagodljivost. Sedenje in počitek kot način uporabe javnih prostorov stanovalcem nista bila pomembna (slika 3), sproščanje pa se je izkazalo za najpomembnejše. Morebiten razlog za to je neprimerno ulično pohištvo na javnih prostorih v Teheranu. Anketiranci so menili, da bi bila umestitev restavracije ali kavarne v sosesko povezana tudi z drugimi dejavniki, kot so površine za sedenje, zato tovrstni prostorski posegi omogočajo najboljši način spoznavanja ljudi v soseski in pritegovanja nove gostin- 
Preglednica 7: Relativne uteži dejavnikov družbene kategorije

\begin{tabular}{lllllllll}
\hline & Sproščanje & Igrišče & $\begin{array}{l}\text { Posedanje v } \\
\text { kavarni }\end{array}$ & $\begin{array}{l}\text { Galerija na } \\
\text { prostem }\end{array}$ & Namizne igre & $\begin{array}{l}\text { Sedenje in } \\
\text { počitek }\end{array}$ & $\begin{array}{l}\text { Šport in rekre- } \\
\text { acija }\end{array}$ \\
\hline Sproščanje & 1 & 3,436 & 3,527 & 4,506 & 3,235 & 1,744 & 3,091 \\
\hline Igrišče & 0,291 & 1 & 1,453 & 3,392 & 2,868 & 1,928 & 2,098 \\
\hline Posedanje v kavarni & 0,283 & 0,688 & 1 & 4,398 & 4,073 & 3,069 & 4,214 \\
\hline Galerija na prostem & 0,221 & 0,294 & 0,227 & 1 & 1,126 & 1,601 & 2,254 \\
\hline Namizne igre & 0,309 & 0,348 & 0,2467 & 0,888 & 1 & 1,826 & 2,091 \\
\hline Sedenje in počitek & 0,573 & 0,450 & 0,325 & 0,624 & 0,547 & 1 & 3,664 \\
\hline Šport in rekreacija & 0,323 & 0,476 & 0,237 & 0,443 & 0,478 & 0,272 & 1 \\
\hline
\end{tabular}

Opombe: $\lambda_{\max }=7,638 ; C l=0,106 ; C R=0,080$.

Preglednica 8: Relativne uteži dejavnikov oblikovalske kategorije

\begin{tabular}{llllll}
\hline & & \multicolumn{5}{c}{ Oblikovalska kategorija } \\
\hline & Topografija & Pravilna zasnova & Raznovrstnost & Gostota & Nepravilna zasnova \\
\hline Topografija & 1 & 3,346 & 1,677 & 2,651 & 1,388 \\
\hline Pravilna zasnova & 0,298 & 1 & 1,519 & 1,265 & 1,712 \\
\hline Raznovrstnost & 0,596 & 0,658 & 1 & 2,893 & 2,128 \\
\hline Gostota & 0,377 & 0,790 & 0,345 & 1 & 2,134 \\
\hline Nepravilna zasnova & 0,720 & 0,584 & 0,469 & 0,468 & 1 \\
\hline
\end{tabular}

Opombe: $\lambda_{\text {max }}=5,415 ; \mathrm{Cl}=0,104 ; \mathrm{CR}=0,093$.

Preglednica 9: Relativne uteži dejavnikov estetske kategorije

\begin{tabular}{llllll}
\hline & \multicolumn{5}{c}{ Estetska kategorija } \\
\hline & Barva & Vzorec & Kip & Instalacija & Poslikava, stenski okras \\
\hline Barva & 1 & 3,315 & 3,227 & 2,862 & 3,113 \\
\hline Vzorec & 0,301 & 1 & 2,604 & 2,097 & 3,228 \\
\hline Kip & 0,309 & 0,383 & 1 & 1,322 & 3,245 \\
\hline Instalacija & 0,349 & 0,476 & 0,756 & 1 & 4,420 \\
\hline Poslikava, stenski okras & 0,321 & 0,309 & 0,308 & 0,226 & 1 \\
\hline
\end{tabular}

Opombe: $\lambda_{\max }=5,401 ; \mathrm{Cl}=0,100 ; \mathrm{CR}=0,090$.

ske ponudbe na območje. Čeprav je bila rekreacija v anketi dosledno ovrednotena kot najpomembnejša aktivnost (63\% anketirancev uporablja odprte javne prostore za sprehajanje, $23 \%$ pa za športno aktivnost), je bila ureditev prostora za rekreacijo najmanj zaželen prostorski poseg. Stanovalci se raje sprehajajo kot pa rekreirajo na majhnih javnih prostorih. $\mathrm{V}$ kategoriji oblikovalskih dejavnikov (slika 5) sta bili najpomembnejši topografija in raznovrstnost, najmanj pomembna pa je bila nepravilna zasnova javnih prostorov.

Čeprav sta bila razgibano površje in raznovrstne zasaditve ovrednotena kot pomembna oblikovalska dejavnika, je bila ureditev prostora z gosto vegetacijo najmanj zaželena. Anketiranci poleg tega niso bili naklonjeni prostorskim ureditvam pod nivojem okolice, saj so menili, da bi se takšni prostori spremenili v smetišča. V nestrukturiranih intervjujih so anketi- ranci navedli, da gosta vegetacija krni vidljivost, kar zmanjšuje varnost in povečuje verjetnost kaznivih dejanj. Ena izmed anketirank je opozorila na nevarne zapuščene prostore podobne velikosti v soseski, zaradi česar je vztrajala, da sta vidljivost in redka vegetacija pomembni za zagotavljanje varnosti. Drugi pa so navedli, da okoljski dejavniki, kot je gosta vegetacija, omogočajo kršenje družbenih norm. Vidljivost v prostoru je bila torej ena najpomembnejših spremenljivk za stanovalce. Druga anketiranka je izjavila, da ko se je pred nekaj dnevi s svojim možem sprehajala po soseski, sta si na proučevanem prostoru zamislila manjši park nepravilne zasnove z nekaj klopmi. Eden izmed anketirancev pa se ni strinjal z nobeno prostorsko rešitvijo, prikazano v anketi. Menil je, da so za sosesko primerni samo oblikovalski posegi, kot je ureditev postajališča za taksije ali parkirišča. Med estetskimi dejavniki (slika 6) je bila najpomembnejša barva, najmanj pomembne pa so bile stenske po- 


\begin{tabular}{|c|c|c|c|c|c|}
\hline Kategorija & Prikaz & $\begin{array}{l}\text { Utež } \\
\text { AHP }\end{array}$ & Kategorija & Prikaz & $\begin{array}{l}\text { Utež } \\
\text { AHP }\end{array}$ \\
\hline Sproščanje & & 0,317 & $\begin{array}{l}\text { Namizne } \\
\text { igre }\end{array}$ & & 0,0843 \\
\hline $\begin{array}{l}\text { Posedanje } \\
\text { v kavarnah }\end{array}$ & & 0,205 & $\begin{array}{l}\text { Galerija na } \\
\text { prostem }\end{array}$ & & 0,0863 \\
\hline Igrišče & & 0,1778 & $\begin{array}{l}\text { Šport in } \\
\text { rekreacija }\end{array}$ & & 0,0493 \\
\hline $\begin{array}{l}\text { Počitek in } \\
\text { sproščanje }\end{array}$ & & 0,0797 & & & \\
\hline
\end{tabular}

Slika 4: Relativna pomembnost družbenih dejavnikov (ilustracija: avtorji)

\begin{tabular}{|c|c|c|c|c|c|}
\hline Kategorija & Prikaz & $\begin{array}{l}\text { Utež } \\
\text { AHP }\end{array}$ & Kategorija & Prikaz & $\begin{array}{l}\text { Utež } \\
\text { AHP }\end{array}$ \\
\hline Topografija & & 0,340 & Gostota & & 0,137 \\
\hline Raznovrstnost & & 0,221 & $\begin{array}{l}\text { Nepravilna } \\
\text { zasnova }\end{array}$ & & 0,115 \\
\hline $\begin{array}{l}\text { Pravilna } \\
\text { zasnova }\end{array}$ & & 0,185 & & & \\
\hline
\end{tabular}

Slika 5: Relativna pomembnost oblikovalskih dejavnikov (ilustracija: avtorji) 


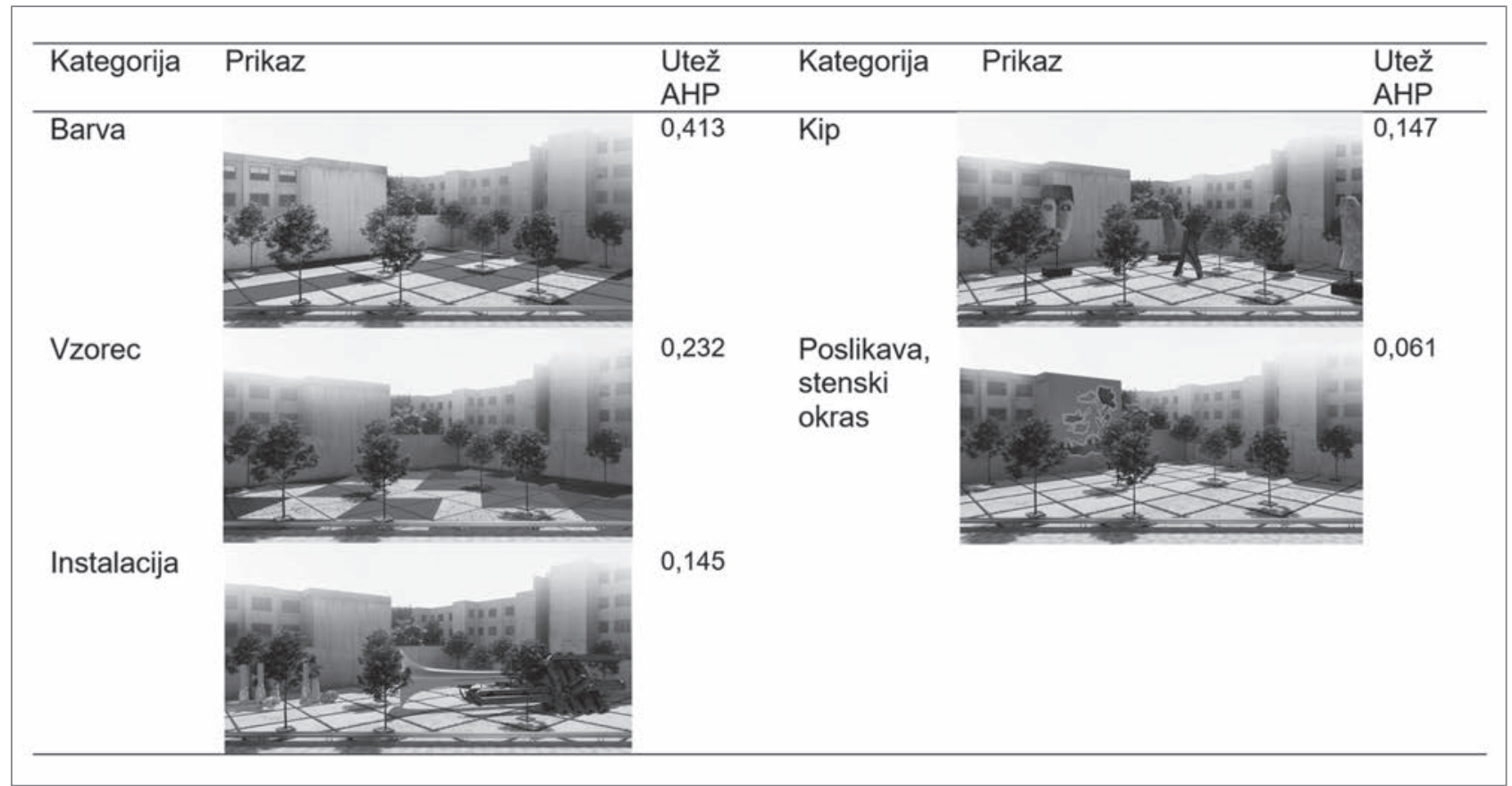

Slika 6: Relativna pomembnost estetskih dejavnikov (ilustracija: avtorji)

slikave. Čeprav je bila prikazana poslikava anketirancem všeč, niso bili prepričani, ali si jo dejansko tudi želijo.

Razlika v pomembnosti barve in stenskih poslikav je bila razvidna tudi iz intervjujev. Na primer, ena izmed anketirank je navedla, da so vpliv barve na človekovo počutje potrdile že raziskave, stenske poslikave pa lahko vključujejo motive in koncepte, ki niso po njenem okusu. Neki moški je izjavil naslednje: »Poslikava bi bila moja prva izbira, če ne bi živel v Teheranu. Glede na trenutno zelo slabo kakovost stenskih poslikav v mestu bom ta dejavnik določil kot najmanj pomemben. Iz enakega razloga ne bom izbral kipa.« Drugi anketiranec je menil, da lahko poslikave polepšajo zunanje zidove stavb in tla, reklame in grafiti po zidovih pa so vizualno moteči in jih je težko odstraniti. Ker se kar 81,21 \% anketirancev zvečer in ponoči zadržuje v manjših parkih, bi bila lahko razloga za to, da poslikav niso ovrednotili kot pomembnih, tudi tema in slaba vidljivost.

Raziskava je odličen primer uporabe metode AHP za proučevanje uporabniških preferenc, ki so lahko v pomoč pri prostorskem oblikovanju in odločanju. Urbanistično oblikovanje je interdisciplinaren proces, pri katerem morajo odločevalci in oblikovalci dobro poznati in upoštevati vse pomembne vidike. Preference stanovalcev in mnenja strokovnjakov kažejo, da je lahko odločanje o tem, kaj in koliko narediti, učinkovito samo, če temelji tako na deskriptivni kot preskriptivni analizi. $Z$ uporabo minimalnih posegov, ki hkrati poskrbijo za varnost in preprečujejo vandalizem, lahko javni prostori ostanejo aktivni.
Navedeno se sklada s pristopom urbane akupunkture. Čeprav so anketiranci pokazali zanimanje za estetske posege, jih zaradi podobnih posegov, ki trenutno potekajo v mestu, niso izbrali za najpomembnejše. Zdi se, da jih bolj kot kipi zanimajo instalacije, ker so samo začasne in jih je mogoče menjavati. $S$ tega vidika se zdi pri izbiri posegov ključno upoštevati tudi to, ali so trajni ali začasni. Čeprav je izbrani prostor majhen, je mogoče učinkovito izbrati vrsto posega z vidika prostorske rabe. Tovrstni majhni javni prostori imajo lahko najrazličnejšo rabo in pomembno vplivajo na spreminjanje mestnega okolja.

\section{Sklep}

Raziskava je pokazala, da so oblikovalski prostorski posegi med stanovalci najbolj zaželeni, pri čemer je treba paziti, da vrsta in gostota vegetacije ne ogrožata varnosti. Poleg tega je pomembna uporaba raznovrstne vegetacije, zlasti kombinacija listavcev in iglavcev, ki poskrbi za raznovrstnost prostora $\mathrm{v}$ vseh letnih časih. Ob upoštevanju navedenih podrobnosti se lahko izvedejo minimalni posegi v prostor, ki se ujemajo $s$ preferencami uporabnikov. Anketiranci so poleg tega pokazali zanimanje za estetske posege, ki so začasni in se lahko menjavajo. Navedeno kaže na to, da bi bilo treba pri izbiri prostorskih posegov upoštevati tudi to, ali so začasni ali trajni. Pomembna je tudi vrsta uličnega pohištva, ki lahko izboljša kakovost prostora in posledično močno vpliva na to, kako pogosto stanovalci uporabljajo prostor. Da bi novi prostorski posegi učinkovito spodbudili urbano prenovo, se morajo ujemati s preferencami 
in željami lokalne skupnosti. Načrtovalci morajo zato upoštevati izkušnje, pridobljene pri prejšnjih projektih, in izbrati najboljše posege na podlagi razvrščanja in vrednotenja njihovih značilnosti.

V zadnjih desetletjih so bili neizkoriščeni odprti mestni prostori obravnavani negativno, raziskave pa so pokazale, da se lahko preobrazijo v manjše javne prostore, ki koristijo lokalni skupnosti in celotnemu mestu. Posegi na neizkoriščenih zemljiščih morajo biti prilagojeni značilnostim konkretnega mestnega okolja. V prihodnje bi bilo smiselno podobne raziskave izvesti tudi na drugih območjih $\mathrm{z}$ drugačno kulturo $\mathrm{v}$ drugem družbenem okolju, da bi ugotovili, ali so med njimi kake pomembnejše razlike. Mnenja stanovalcev in strokovnjakov bi lahko primerjali v okviru nadaljnjih raziskav in anket, pri vrednotenju preferenc stanovalcev glede različnih posegov v fazi oblikovanja pa bi bila lahko koristna uporaba virtualne resničnosti $v$ anketah.

Maryam Naghibi, Iran University of Science and Technology (IUST), School of Architecture and Environmental Design, Teheran, Iran E-naslov: maryam_naghibi@arch.iust.ac.ir

Mohsen Faizi, Iran University of Science and Technology (IUST), School of Architecture and Environmental Design, Teheran, Iran E-naslov:mfaizi@iust.ac.ir

Ahmad Ekhlassi, Iran University of Science and Technology (IUST), School of Architecture and Environmental Design, Teheran, Iran E-naslov: ekhlassi@iust.ac.ir

\section{Viri in literatura}

Acebillo, J. A. (2006): Barcelona: Towards a new urban planning approach. Spatium, 13-14, str. 55-59. DOI: 10.2298/SPAT0614055A

Ahern, J. (1999): Spatial concepts, planning strategies and future scenarios: A framework method for integrating landscape ecology and landscape planning. V: Klopatek, J., in Gardner, R. (ur.): Landscape Ecological Analysis: Issues and Applications, str. 175-201. New York, Springer. DOI: 10.1007/978-1-4612-0529-6

Aouad, D. (2016): Urban acupuncture as a tool for today's re-naturalization of the city: The non-constructible parcels of municipal Beirut through the case study of Saifi district. V: Rodrigues Couceiro da Costa, M. J., Roseta F., Couceiro da Costa, S., in Pestana Lages, J. (ur.): Procedings of the EAAE ARCC 10th international conference (EAAE ARCC 2016), 15-18 June 2016, Lisbon, Portugal, str. 629-636. Boca Raton, FL, CRC Press. DOI: $10.1201 / 9781315226255-96$

Armstrong, H. (2006): Time, dereliction and beauty: An argument for landscapes of contempt. V: The landscape architect. IFLA conference papers May 2006, str. 116-127. Canberra, Australian Institute of Landscape Architects.

Bahrami, B., Salehi, E., Jafari, H., in Behbahani, H. I. (2012): Urban ecological landscape planning and design from garden city toward modern city - a case study: Tehran city in Iran. International Journal on Technical and Physical Problems of Engineering, 11(4), str. 128-134.
Behzadfar, M., Abdi, F., in Mohammadi, M. (2014): Promotion of the pedestrian-based capacity of major urban spaces of Farahzad village of Tehran. International Journal of Architectural Engineering \& Urban Planning, 24(1), str. 45-55.

Bugaric, B. (2018): Urban acupuncture treatment implementing communication tools with youth in Ljubljana suburbs. Urbani izziv, 29, str. 95-108. DOI: 10.5379/urbani-izziv-en-2018-29-supplement-006

Campelo, A., in Fontenele, D. (2017): Sustainable development for recovering economic crisis: A possible solution for Brazil. V: Brebbia, C. A., in Sendra, J. J. (ur.): The sustainable city XII (= WIT transactions on ecology and the environment 223), str. 39-45. Ashurst, VB, WIT Press. DOI: $10.2495 /$ SC170041

Casagrande, M. (2015): From urban acupuncture to the third generation city. V: Revedin, J. (ur.): La ville rebelle. Démocratiser le projet urbain, str. 1-22. Pariz, Gallimard.

Casanova, H., in Hernandez, J. (2015): Public space acupuncture. Barcelona, ACTAR.

Cerro, C. (2018): Developing solutions for dealing with water and food scarcity: Atmospheric water generator and urban farm tower. V: Advances in science and engineering technology international conferences, str. 1-6. Piscataway, NJ, IEEE. DOI: 10.1109/ICASET.2018.8376754

Cheng, S., in Niu, X. (2010): Urban acupuncture based on digital technology. V: Proceeding of 2nd international conference on information science and engineering, ICISE2010, str. 4203-4206. Piscataway, NJ, IEEE. DOI: $10.1109 /$ ICISE.2010.5691876

Colorni, A., Ferretti, V., Lu, A., Oppio, A., Paruscio, V., in Tomasini, L. (2017): Rethinking feasibility analysis for urban development: A multidimensional decision support tool. V: Gervasi, O., Murgante, B., Misra, S., Borruso, G., Torre, C. M., Rocha, A. M. A. C., idr. (ur.): Computational science and its applications - ICCSA 2017, str. 624-638. Cham, Springer. DOI: 10.1007/978-3-319-62398-6

Daniel, T. C. (2001): Whither scenic beauty? Visual landscape quality assessment in the 21st century. Landscape and Urban Planning, 54(1-4), str. 267-281. DOI: 10.1016/S0169-2046(01)00141-4

Daugelaite, A., Gražulevičiūte-Vileniške, I., in Landauskas, M. (2018): Possibilities to apply the urban acupuncture concept in Kaunas: Social aspect. Landscape Architecture and Art, 13(13), str. 18-27. DOI: 10.22616/j.landarchart.2018.13.02

de Sola-Morales, I. (2014): Terrain vague. V: Mariani, M., in Barron, P. (ur.): Terrain vague interstices at the edge of the pale, str. 40-46. New York, Routledge.

De Wit, S. I. (2014): Green galaxies: An interstitial strategy for restorative spaces. V: Cavallo, R., Komossa, S., Marzot, N., Berghauser-Pont, M., in Kuijper, J. (ur.): New urban configurations, str. 1072-1079. Amsterdam, IOS Press.

Drake, L., in Lawson, L. J. (2014): Validating verdancy or vacancy? The relationship of community gardens and vacant lands in the U.S. Cities, 40(B), str. 133-142. DOI: 10.1016/j.cities.2013.07.008

Dubeaux, S., in Cunningham Sabot, E. (2018): Maximizing the potential of vacant spaces within shrinking cities, a German approach. Cities, 75, str. 6-11. DOI: 10.1016/j.cities.2017.06.015

Enia, M., in Martella, F. (2019): Reducing architecture: Doing almost nothing as a city-making strategy in 21 st century architecture. Frontiers of Architectural Research, 8(2), str. 154-163.

DOI: 10.1016/j.foar.2019.01.006

Folke, C. (2006): Resilience: The emergence of a perspective for social-ecological systems analyses. Global Environmental Change, 16(3), str. 253-267. DOI: 10.1016/j.gloenvcha.2006.04.002 
Franck, K. A., in Stevens, Q. (2007): Loose space possibility and diversity in urban life. New York, Routledge. DOI: 10.4324/9780203799574

Gadanho, P. (2015): Uneven growth: Tactical urbanisms for expanding megacities. New York, The Museum of Modern Art.

Greenberg, M., in Lewis, M. J. (2000): Brownfields redevelopment, preferences and public involvement: A case study of an ethnically mixed neighbourhood. Urban Studies, 37(13), str. 2501-2514. DOI: 10.1080/00420980020080661

Grifoni, R. C., Ottone, M. F., in Prenna, E. (2017): Tomographic environmental sections for environmental mitigation devices in historical centers. Energies, 10(3), str. 351-369. DOI: 10.3390/en10030351

Hands, D. E., in Brown, R. D. (2002): Enhancing visual preference of ecological rehabilitation sites. Landscape and Urban Planning, 58(1), str. 57-70. DOI: 10.1016/S0169-2046(01)00240-7

Hofmann, M., Westermann, J. R., Kowarik, I., in van der Meer, E. (2012): Perceptions of parks and urban derelict land by landscape planners and residents. Urban Forestry \& Urban Greening, 11(3), str. 303-312. DOI: 10.1016/j.ufug.2012.04.001

Houghton, K., Choi, J. H., in Lugmayr, A. (2015): From the guest editors: urban acupuncture. Journal of Urban Technology, 22(3), str. 1-2. DOI: $10.1080 / 10630732.2015 .1087684$

Johnson, M. P., Hollander, J., in Hallulli, A. (2014): Maintain, demolish, re-purpose: Policy design for vacant land management using decision models. Cities, 40, str. 151-162. DOI: 10.1016/j.cities.2013.05.005

Kamvasinou, K. (2011): The public value of urban vacant land. Proceedings of the Institution of Civil Engineers: Municipal Engineer, 164(3), str. 157-166. DOI: 10.1680/muen.9.00020

Kermani, A. A. (2016): Developing a framework for qualitative evaluation of urban interventions in Iranian historical cores. $A+B E$ Architecture and the Built Environment, 10, str. 1-212. DOI: 10.7480/abe.2016.10

Khorshidifard, S. (2014): Hidden in plain sight: Tehran's empowering protean spaces. Doktorska disertacija. Milwaukee, The University of Wisconsin-Milwaukee.

Kim, G. (2016): The public value of urban vacant land: Social responses and ecological value. Sustainability, 8(5), str. 486-505.

DOI: $10.3390 /$ su8050486

Kim, E. J., in Miller, P. (2017): Residents' perception of local brownfields in rail corridor area in the City of Roanoke: The effect of people's preconception and health concerns factors. Journal of Environmental Planning and Management, 60(5), str. 862-882.

DOI: $10.1080 / 09640568.2016 .1182898$

Kim, G., Newman, G., in Jiang, B. (2020): Urban regeneration: Community engagement process for vacant land in declining cities. Cities, 102(April), str. 1-12. DOI: 10.1016/j.cities.2020.102730

Kremer, P., Hamstead, Z. A., in McPhearson, T. (2013): A social-ecological assessment of vacant lots in New York City. Landscape and Urban Planning, 120, str. 218-233. DOI: 10.1016/j.landurbplan.2013.05.003

Lafortezza, R., Corry, R. C., Sanesi, G., in Brown, R. D. (2008): Visual preference and ecological assessments for designed alternative brownfield rehabilitations. Journal of Environmental Management, 89(3), str. 257-269. DOI: 10.1016/j.jenvman.2007.01.063

Lastra, A., in Pojani, D. (2018): Urban acupuncture to alleviate stress in informal settlements in Mexico. Journal of Urban Design, 23(5), str. 749-762. DOI: 10.1080/13574809.2018.1429902

Lerner, J. (2014): Urban acupuncture. Berlin, Springer. DOI: 10.5822/978$1-61091-584-7$
Lokman, K. (2017): Vacancy as a laboratory: Design criteria for reimagining social-ecological systems on vacant urban lands. Landscape Research, 42(7), str. 728-746. DOI: 10.1080/01426397.2017.1355446

Loukaitou-Sideris, A. (1996): Cracks in the city: Addressing the constraints and potentials of urban design. Journal of Urban Design, 1(1), str. 91-103. DOI: 10.1080/13574809608724372

Lydon, M., Garcia, A., in Duany, A. (2015): Tactical urbanism: Short-term action for long-term change. Washington, Island Press. DOI: 10.5822/978-1-61091-567-0

Lynch, K. (1977): The image of the city. Cambridge, MA, MIT Press.

Map data (2020): Dostopno na: https://www.google.com/maps/search/ Teheran,+Tehran,+Zafar+Street,+Iran/@35.6888203,51.4622624,10.75z (sneto 11. 5. 2020).

Mariani, M., in Barron, P. (2014): Terrain vague: Interstices at the edge of the pale. New York, Routledge.

Marzi, M., in Ancona, N. (2004): Urban acupuncture, a proposal for the renewal of Milan's urban ring road. 40th ISoCaRP congress, str. 1-12. Milan, ISoCaRP.

Mondini, G., Fattinnanzi, E., Oppio, A., in Bottero, M. (2018): Integrated evaluation for the management of contemporary cities. Berlin, Springer. DOI: 10.1007/978-3-319-78271-3

Nekhay, O., in Arriaza, M. (2016): How attractive is upland olive groves landscape? Application of the analytic hierarchy process and GIS in southern Spain. Sustainability, 8(11), str. 1-16. DOI: 10.3390/su8111160

Nemeth, J., in Langhorst, J. (2014): Rethinking urban transformation: Temporary uses for vacant land. Cities, 40, str. 143-150.

DOI: 10.1016/j.cities.2013.04.007

Newman, G., in Kim, B. (2017): Urban shrapnel: Spatial distribution of non-productive space. Landscape Research, 42(7), str. 699-715. DOI: 10.1080/01426397.2017.1363877

Newman, G., Park, Y., Bowman, A. O. M., in Lee, R. J. (2018): Vacant urban areas: Causes and interconnected factors. Cities, 72(B), str. 421-429. DOI: 10.1016/j.cities.2017.10.005

Norouzian-Maleki, S., Bell, S., Hosseini, S.-B., Faizi, M., in Saleh-Sedghpour, B. (2018): A comparison of neighbourhood liveability as perceived by two groups of residents: Tehran, Iran and Tartu, Estonia. Urban Forestry \& Urban Greening, 35, str. 8-20. DOI: 10.1016/j.ufug.2018.08.004

Palmer, J. F., in Hoffman, R. E. (2001): Rating reliability and representation validity in scenic landscape assessments. Landscape and Urban Planning, 54(1-4), str. 149-161. DOI: 10.1016/S0169-2046(01)00133-5

Pearsall, H., in Lucas, S. (2014): Vacant land: The new urban green? Cities, 40, str. 121-123. DOI: 10.1016/j.cities.2013.10.001

Peng, S.-H. (2019): Landscape assessment for stream regulation works in a watershed using the analytic network process (ANP). Sustainability, 11(6), 1540. DOI: 10.3390/su11061540

Polat, S., in Tümer Yildiz, H. Ö. (2019): Vključenost lokalne skupnosti v pripravo smernic za urbanistično oblikovanje na območjih kulturne dediščine: primer Burse v Turčiji. Urban izziv, 30(2), str. 5-19. DOI: 10.5379/urbani-izziv-2019-30-02-001

Radstaak, S. (2012): Urban acupuncture in Rotterdam: As an apporach towards urban identity. Magistrsko delo. Wageningen, Wageningen University.

Rau, P.-L. P., in Hutchison, D. (2019): Cross-cultural design. Berlin, Springer. 
Ruelle, C., Halleux, J. M., in Teller, J. (2013): Landscape quality and brownfield regeneration: A community investigation approach inspired by landscape preference studies. Landscape Research, 38(1), str. 75-99. DOI: $10.1080 / 01426397.2011 .647898$

Saaty, T. L. (1990): How to make a decision: The analytic hierarchy process. European Journal of Operational Research, 48(1), str. 9-26. DOI: 10.1016/0377-2217(90)90057-I

Saaty, T., in De Paola, P. (2017): Rethinking design and urban planning for the cities of the future. Buildings, 7(3), str. 76-98.

DOI: 10.3390/buildings7030076

Shieh, L. (2006): Urban acupuncture as a strategy for São Paulo. Master's thesis. Cambridge, MA, MIT University.

Steinitz, C. (2001): Visual evaluation models: Some complicating questions regarding memorable scenes. Landscape and Urban Planning, 54(1-4), str. 283-287. DOI: 10.1016/S0169-2046(01)00142-6

Svobodova, K., Sklenicka, P., Molnarova, K., in Salek, M. (2012): Visual preferences for physical attributes of mining and post-mining landscapes with respect to the sociodemographic characteristics of respondents. Ecological Engineering, 43, str. 34-44.

DOI: 10.1016/j.ecoleng.2011.08.007

Thompson, C. W. (2002): Urban open space in the 21st century. Landscape and Urban Planning, 60(2), str. 59-72.

DOI: 10.1016/S0169-2046(02)00059-2

Tortosa, L., Vicent, J. F., Zamora, A., in Oliver, J. L. (2010): A neural network model to develop urban acupuncture. V: Setchi, R., Jordanov, I., Howlett R. J., in Jain L. C. (ur.): Knowledge-based and intelligent information and engineering systems. KES 2010 (= Lecture notes in computer science 6276), str. 31-40. Berlin, Springer.

DOI: 10.1007/978-3-642-15387-7_7

Trancik, R. (1986): Finding lost space. New York, Routledge.

Tveit, M., Ode, A., in Fry, G. (2006): Key concepts in a framework for analysing visual landscape character. Landscape Research, 31(3), str. 229-255. DOI: 10.1080/01426390600783269

Unt, A. L., in Bell, S. (2014): The impact of small-scale design interventions on the behaviour patterns of the users of an urban wasteland. Urban Forestry \& Urban Greening, 13(1), str. 121-135.

DOI: 10.1016/j.ufug.2013.10.008

Unt, A. L., Travlou, P., in Bell, S. (2014): Blank space: Exploring the sublime qualities of urban wilderness at the former Fishing Harbour in Tallinn, Estonia. Landscape Research, 39(3), str. 267-286. DOI: 10.1080/01426397.2012.742046

Wals, A. E. J., in Wals, A. E. J. (2015): Social learning towards a sustainable world: Principles, perspectives, and praxis. Wageningen, Wageningen Academic Publishers. DOI: 10.1016/j.njas.2014.04.001

Zhang, Z., Meerow, S., Newell, J. P., in Lindquist, M. (2019): Enhancing landscape connectivity through multifunctional green infrastructure corridor modeling and design. Urban Forestry \& Urban Greening, 38, str. 305-317. DOI: 10.1016/j.ufug.2018.10.014

Zhao, M., Zhang, J., in Cai, J. (2020): Influences of new high-rise buildings on visual preference evaluation of original urban landmarks: A case study in Shanghai, China. Journal of Asian Architecture and Building Engineering, 19(3), str. 273-284. DOI: 10.1080/13467581.2020.1729769 